\title{
EFEKTIVITAS TERAPI MUROTTAL AL-QUR'AN TERHADAP TEKANAN DARAH IBU HAMIL DENGAN HIPERTENSI
}

\author{
Pegi Melati' ${ }^{1}$ Yulia Irvani Dewi ${ }^{2}$, Reni Zulfitri ${ }^{3}$ \\ 1,2,3 Fakultas Keperawatan Universitas Riau Jalan Pattimura No 9 Gedung G Pekanbaru Riau \\ e-mail: pegi08m@gmail.com
}

\begin{abstract}
Abstrak
Hipertensi merupakan suatu kondisi terjadi peningkatan tekanan darah yang terjadi pada semua fase kehidupan salah satunya fase kehamilan. Ibu hamil dengan hipertensi sangat beresiko menimbulkan komplikasi baik itu kepada ibu maupun janin. Tekanan darah pada ibu hamil dengan hipertensi dapat dikontrol melalui terapi non farmakologis yaitu Murottal Al-Qur'an. Penelitian ini bertujuan untuk mengetahui efektivitas terapi Murottal Al-Qur'an terhadap penurunan tekanan darah pada ibu hamil. Penelitian ini menggunakan metode quasi eksperimen dengan desain penelitian one group pretest-posttest. Sampel berjumlah 15 responden berdasarkan kriteria inklusi dan eksklusi dengan teknik purposive sampling. Semua responden diberikan intervensi 15 menit selama 6 hari berturut-turut. Murottal Al-Qur'an yang dipakai terdiri dari surah Al-Fatihah, Ayat Kursi (Al-Baqarah ayat 255), dan tiga Qul (Al-Ikhlas, Al-Falaq, dan An-Naas) disertai terjemahan masing-masing surah tersebut. Tekanan darah diukur secara langsung menggunakan sphygmomanometer jarum dan stetoskop. Hasil uji wilcoxon test diperoleh $p$ value $=0,001$ $(\mathrm{p}<\alpha(0,05))$ dapat disimpulkan bahwa terapi Murottal Al-Qur'an efektif untuk menurunkan tekanan darah ibu hamil dengan hipertensi. Disarankan kepada petugas kesehatan yang beragama Islam agar dapat memberikan terapi Al-Qur'an sebagai terapi non farmakologis menurunkan tekanan darah ibu hamil hipertensi.
\end{abstract}

Kata kunci: hipertensi, ibu hamil, terapi murottal Al-Qur'an

\begin{abstract}
Hypertension diseases is a condition of increased blood pressure occurs in all phases of life, included pregnancy phase. Pregnant women who have hypertension is risky in case of complication to the pregnancy and the fetus. Blood pressure in pregnant women with hypertension controllable by non-pharmacological therapy, namely Murottal Al-Qur'an therapy. This research aims to determine the effectiveness of Murottal Al-Qur'an therapy for decreasing blood pressure in pregnant women with hypertension. This research was quasy experimental study with one group pretest-posttest design. The sample was 15 respondents which taken based on inclusion and exclusion criteria through purposive sampling technique. All respondents were given a 15-minute intervention for 6 consecutive days. Murottal Al-Qur'an used consists of Al-Fatihah, Ayat Kursi (Al-Baqarah: 255), and three Qul (Al-Ikhlas, Al-Falaq, and An-Naas) accompanied of each translation. Blood pressure was measured directly using a needle sphygmomanometer and stethoscope. The wilcoxon test
\end{abstract}


Pegi Melati, Yulia Irvani Dewi, dan Reni Zulfitri, Efektivitas Terapi Murottal Al-Qur'an terhadap Tekanan Darah Ibu Hamil dengan Hipertensi

statistic results obtained $p$ value $p$ value $=0,001(p<\alpha(0,05))$ so it can be concluded that Murottal Al-Qur'an therapy is effective for decreasing blood pressure in pregnant women with hypertension. It is recommended to health workers who are Muslim to provide Murottal Al-Qur'an therapy as a non-pharmacological therapy to decrease blood pressure in pregnant women with hypertension.

Keywords: hypertension, murottal Al-Qur'an therapy, pregnant women

\section{PENDAHULUAN}

Hipertensi dalam kehamilan adalah kelainan vaskuler yang dapat terjadi pada usia gestasi $<20$ minggu atau $\geq 20$ minggu. Timbulnya hipertensi akibat dari vasospasme menyeluruh dengan ukuran tekanan darah sistolik $\geq 140 \mathrm{mmHg}$ atau tekanan diastolik $\geq 90 \quad \mathrm{mmHg}$ pada selang enam jam (Prawirohardjo, 2010). Jenis hipertensi dalam kehamilan dapat diklasifikasikan menjadi hipertensi kronik, preeklampsia, eklampsia, kronik dengan superimposed preeclampsia, dan gestasional (Hurt et al., 2011).

Penyebab pasti hipertensi dalam kehamilan belum diketahui, akan tetapi terdapat faktor risiko terjadinya hipertensi, diantaranya keturunan, usia $<20$ tahun atau $>35$ tahun, kehamilan pertama kali, kebiasaan makan yang banyak mengandung garam, obesitas, stress (Abrahams, 2014; Indriyani, 2013).
Angka kejadian hipertensi dalam kehamilan di dunia menyebabkan kematian maternal (10\%) dan penyebab bayi lahir dengan Berat Badan Lahir Rendah (BBLR). Kematian maternal mendekati $99 \%$ terjadi di negara berkembang dan sisanya terjadi di negara maju (World Health Organization, 2018). Prevalensi kematian maternal di Indonesia masih cukup tinggi yang penyebab obstetrik berupa perdarahan (30,3\%), hipertensi dalam kehamilan $(27,1 \%)$, dan infeksi (7,3\%). Sementara itu penyebab non-obstetrik: penyakit kanker, jantung, ginjal, tuberkulosis, serta penyakit lain yang diderita ibu berperan cukup besar yaitu sebesar $40,8 \%$ (Kementerian Kesehatan Republik Indonesia, 2017).

Prevalensi hipertensi dalam kehamilan di Provinsi Riau tahun 2016 memperoleh angka tertinggi yaitu sebesar 26\% (Dinas Kesehatan Provinsi Riau, 2016). Kota Pekanbaru juga 
didapati prevalensi hipertensi pada kehamilan masih relatif tinggi, yaitu sebesar 17\% (Dinas Kesehatan Kota Pekanbaru, 2017).

Hasil penelitian yang dilakukan Khosravi, Dabiran, Lotfi, dan Asnavandy (2014) menyatakan bahwa terdapat komplikasi hipertensi pada ibu hamil dengan sindrom HELLP (Hemolysis, Elevated Liver Enzymes \& Low Platelet count) sebesar $4,9 \%$ dari kasus, bayi lahir prematur $(52,6 \%)$, kematian janin dalam kandungan $(7,4 \%)$, IUGR (intrauterine growth retardation) $(9,9 \%)$, dan berat badan lahir rendah $(17,3 \%)$. Komplikasi tersebut dapat dicegah dengan penatalaksanaan yang tepat.

Penatalaksanaan hipertensi pada kehamilan dapat diberikan melalui terapi farmakologis (penggunaan obat-obatan antihipertensi) dan terapi non-farmakologis (tidak menggunakan obat-obatan). Terapi non-farmakologis yang dapat diberikan diantaranya adalah Murottal Al-Qur'an (mendengarkan bacaan ayat-ayat Al-Qur'an).

Al-Qur'an ketika dibacakan akan merangsang area dalam otak terutama pada amygdala (respon emosi), hippocampus (respon ingatan emosional), dan pre-frontal (pemaknaan peristiwa) akan semakin banyak dan dengan mengetahui makna ayat mampu memberikan dampak yang menakjubkan bagi psikis dan spiritual (Pedak, 2009).

Hasil penelitian yang dilakukan oleh Lukito (2017) menjelaskan bahwa ayat-ayat Al-Qur'an merangsang hormon endofrin dalam tubuh dengan menghasilkan perasaan rileks dan memperbaiki sistem kimia dalam tubuh. Penelitian lain oleh Ropei dan Luthfi (2017) mengkhususkan memakai surah Al-Fatihah, Ayat Kursi, dan tiga Qul dengan intervensi selama 12 menit 17 detik berpengaruh menurunkan tekanan darah.

Hasil studi pendahuluan tanggal 26 November 2018 dilakukan wawancara pada 2 ibu hamil dengan hipertensi yang mengatakan tidak pernah mendapatkan terapi non-farmakologis seperti terapi Al-Qur'an untuk menurunkan tekanan darah. Petugas kesehatan di Puskesmas juga mengatakan belum pernah memberikan terapi non-farmakologis seperti mendengarkan ayat Al-Qur'an kepada ibu hamil hipertensi.

Berdasarkan fenomena tersebut peneliti 
Pegi Melati, Yulia Irvani Dewi, dan Reni Zulfitri, Efektivitas Terapi Murottal Al-Qur'an terhadap Tekanan Darah Ibu Hamil dengan Hipertensi

terdorong untuk melakukan penelitian

efektivitas Murottal Al-Qur'an kepada ibu hamil dengan hipertensi sebagai bentuk terapi non-farmakologis dalam menurunkan tekanan darah.

\section{METODE PENELITIAN}

Penelitian yang dilakukan merupakan penelitian quasi eksperimen dengan pendekatan one group pretest-posttest. Jumlah populasi adalah semua ibu hamil hipertensi di wilayah kerja Puskesmas Rejosari, Tenayan Raya, dan Rawat Inap Sidomulyo. Sampel berjumlah 15 dengan teknik purposive sampling. Alat ukur menggunakan sphygmomanometer jarum dan stetoskop yang pengukurannya langsung pada responden.

Peneliti melakukan kunjungan rumah (home visit) pada masing-masing responden. Pengukuran tekanan darah dilakukan selama 6 hari berturut-turut. Tekanan darah diukur sebelum dan sesudah diberikan terapi murottal Al-Qur'an terdiri dari lima surah yaitu Surah Al-Fatihah, Al-Baqarah ayat 255 (Ayat Kursi), Al-Ikhlas, Al-Falaq, dan An-Naas disertai

terjemahan masing-masing surah selama 15 menit. Analisis univariat dan bivariat dengan uji alternatif wilcoxon.

\section{HASIL PENELITIAN}

\section{Karakteristik responden}

Karakteristik responden mencakup usia ibu, usia kehamilan, dan gravida ibu. Berikut ditampilkan data berupa karakteristik responden:

Tabel 1

Distribusi frekuensi karakteristik usia ibu, usia kehamilan, dan gravida

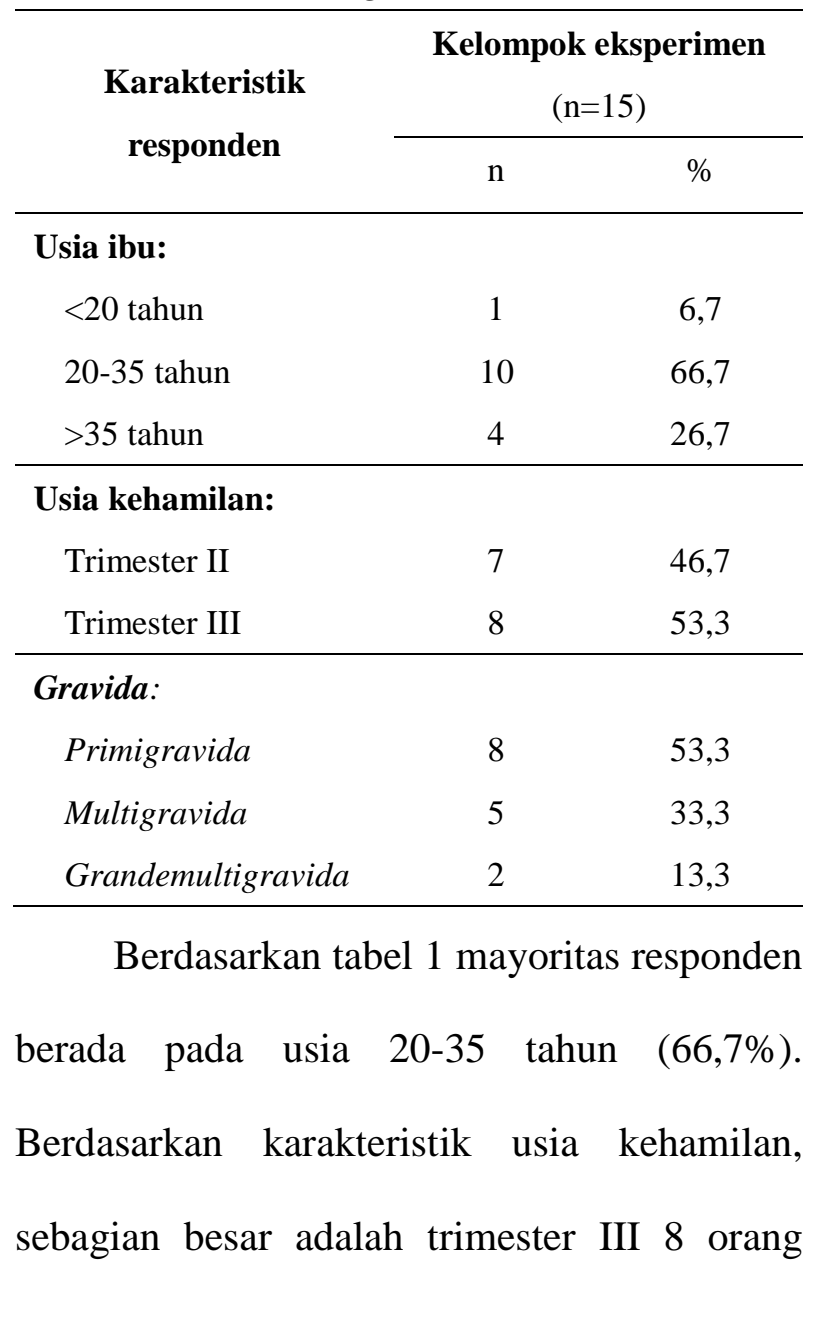


$(53,3 \%)$ dan sisanya berada pada usia kehamilan trimester II, sebanyak 8 orang $(53,3 \%)$ responden adalah primigravida.

\section{Rata-rata tekanan darah sistolik (pre-test dan post-test)}

Tabel 2

Rata-rata tekanan darah sistolik (pre-test dan post-test)

\begin{tabular}{ccccc}
\hline Tekanan & Rata- & Min & Max & n \\
Darah & rata & & & \\
\hline
\end{tabular}

\begin{tabular}{llll}
\hline Sistolik & & & \\
Pretest: & $\mathbf{1 3 7 , 2 2}$ & $\mathbf{1 2 6 , 8 3}$ & $\mathbf{1 5 6 , 1 6}$ \\
- Hari 1 & 140 & 130 & 160 \\
- Hari 2 & 140,80 & 130 & 160 \\
- Hari 3 & 138,67 & 129 & 160 \\
- Hari 4 & 137 & 126 & 155 \\
- Hari 5 & 134,47 & 123 & 154 \\
- Hari 6 & 131,53 & 123 & 150 \\
\hline Sistolik & & & \\
Posttest: & $\mathbf{1 3 1 , 0 5}$ & $\mathbf{1 2 1}$ & $\mathbf{1 4 7}$ \\
- Hari 1 & 134,60 & 123 & 155 \\
- Hari 2 & 133,67 & 123 & 150 \\
- Hari 3 & 131,73 & 120 & 150 \\
- Hari 4 & 130,53 & 120 & 148 \\
- Hari 5 & 130 & 120 & 145 \\
- Hari 6 & 126,80 & 118 & 143 \\
\hline
\end{tabular}

Pada tabel 2 rata-rata tekanan darah semua responden dengan sistolik pre-test hari 1 sampai hari ke-6 adalah 137,22 mmHg. Terjadi penurunan tekanan darah sistolik pre-test dari hari 1 sebesar $140 \mathrm{mmHg}$ menjadi 131,53 mmHg pada hari ke-6. Rata-rata tekanan darah sistolik post-test 131,05 mmHg.
Terjadi penurunan tekanan darah sistolik post-test dari hari 1 sebesar 134,60 $\mathrm{mmHg}$ menjadi 126,80 pada hari ke 6 .

\section{Rata-rata tekanan darah diastolik (Pre-test dan Post-test)}

Tabel 3

Rata-rata tekanan darah diastolik (pre-test dan post-test)

\begin{tabular}{lcccc}
\hline $\begin{array}{c}\text { Tekanan } \\
\text { Darah }\end{array}$ & $\begin{array}{c}\text { Rata- } \\
\text { rata }\end{array}$ & Min & Max & $\mathrm{n}$ \\
\hline Diastolik & & & & \\
Pretest: & $\mathbf{1 3 7 , 2 2}$ & $\mathbf{1 2 6 , 8 3}$ & $\mathbf{1 5 6 , 1 6}$ & \\
- Hari 1 & 140 & 130 & 160 & \\
- Hari 2 & 140,80 & 130 & 160 & \\
- Hari 3 & 138,67 & 129 & 160 & \\
- Hari 4 & 137 & 126 & 155 \\
- Hari 5 & 134,47 & 123 & 154 \\
- Hari 6 & 131,53 & 123 & 150 \\
\hline Diastolik & & & & 15 \\
Postest: & $\mathbf{8 3 , 5}$ & $\mathbf{8 2 , 3 3}$ & $\mathbf{9 2 , 6 6}$ \\
- Hari 1 & 88,67 & 84 & 100 \\
- Hari 2 & 88 & 85 & 94 \\
- Hari 3 & 85 & 82 & 92 \\
- Hari 4 & 84 & 81 & 90 \\
- Hari 5 & 82 & 80 & 90 \\
- Hari 6 & 80 & 79 & 90 \\
\hline
\end{tabular}

Berdasarkan tabel 3 rata-rata tekanan darah diastolik pre-test hari 1 sampai dengan hari ke 6 adalah $89 \mathrm{mmHg}$. Terjadi penurunan tekanan darah diastolik pre-test dari hari 1 sebesar $93 \mathrm{mmHg}$ menjadi $85 \mathrm{mmHg}$ pada hari ke 6. Rata-rata tekanan darah diastolik post-test $83,5 \mathrm{mmHg}$. Penurunan tekanan 
Pegi Melati, Yulia Irvani Dewi, dan Reni Zulfitri, Efektivitas Terapi Murottal Al-Qur'an terhadap Tekanan Darah Ibu Hamil dengan Hipertensi

darah terjadi dari hari 1 sebesar $88,67 \mathrm{mmHg}$ menjadi $80 \mathrm{mmHg}$ pada hari ke 6 .

\section{Perbedaan rata-rata tekanan darah sistolik dan diastolik}

Tabel 4

Rata-rata tekanan darah sistolik dan diastolik

\begin{tabular}{|c|c|c|c|c|c|}
\hline $\begin{array}{c}\text { Tekanan } \\
\text { Darah }\end{array}$ & Median & Min & Max & n & $\mathbf{p}$ \\
\hline
\end{tabular}

\begin{tabular}{llllll}
\hline Sistolik: & & & & & \\
-Pretest & 137,22 & 126,8 & 156,16 & & \\
-Posttest & 131 & 3 & 147 & & \\
& & 121 & & & 0,001 \\
& & & & & \\
Diastolik: & & & & & \\
-Pretest & 89 & 87,5 & 99,6 & & \\
-Posttest & 83,5 & 82,3 & 92,6 & & \\
\hline
\end{tabular}

Tabel 4 ditemukan perbedaan rata-rata tekanan darah sistolik pre-test $137,2 \mathrm{mmHg}$ dan post-test $131 \mathrm{mmHg}$. Perbedaan rata-rata tekanan darah diastolik pre-test $89 \mathrm{mmHg}$ dan post-test $83,5 \mathrm{mmHg}$. Hasil analisa statistik didapatkan $p$ value $=0,001\{\mathrm{p}<\alpha(\alpha=0,05)\}$, dapat disimpulkan bahwa terdapat perbedaan rata-rata tekanan darah sistolik maupun diastolik sebelum dan sesudah diberikan terapi Murottal Al-Qur'an.

\section{PEMBAHASAN}

\section{Karakteristik responden}

\section{a. Usia Ibu}

Sebagian besar usia ibu hamil yang mengalami hipertensi berada pada rentang 20-35 tahun $(66,7 \%)$. Secara biologis rentang usia yang aman untuk hamil adalah 20-35 tahun. Hal ini dikarenakan reproduksi wanita telah berkembang maksimal sehingga dapat mengurangi berbagai resiko ketika kehamilan terjadi, termasuk salah satunya hipertensi dalam kehamilan (Gunawan, 2010). Namun pada penelitian ini ditemukan bahwa Ibu hamil pada usia produktif mengalami hipertensi.

Penelitian Jumaiza, Elvira, dan Panjaitan (2018) menjelaskan bahwa mayoritas usia responden yang mengalami hipertensi dalam kehamilan adalah 20-35 tahun (60\%) dan juga sependapat dengan Basana, Myrnawati, dan Sembiring (2017) bahwa sebanyak 51,3\% ibu hamil hipertensi berusia 20-35 tahun.

Sementara itu ditemukan sebanyak 6,7\% ibu hamil hipertensi $<20$ tahun dan $26,7 \%$ berusia $>35$ tahun. Secara teori usia $<20$ tahun dan atau >35 tahun merupakan usia dengan resiko tinggi (Prawirohardjo, 2010). Endjun (2009) juga menyatakan bahwa ibu hamil >35 tahun beresiko tinggi. Hal ini dikarenakan pada usia lanjut dapat meningkatkan penyulit 
pada kehamilan, seperti hipertensi, diabetes melitus, dan perdarahan.

Mardjan (2016) menyatakan bahwa usia $<20$ tahun dapat menyebabkan kehamilan resiko tinggi yang dikarenakan organ-organ reproduksi internal dan eksternal belum matang seperti uterus, panggul, jalan persalinan belum siap jika terjadi pembuahan, sehingga dapat meningkatkan berbagai resiko yang dapat terjadi. Berdasarkan pernyataan tersebut maka angka kejadian ibu hamil hipertensi terjadi pada semua rentang usia.

\section{b. Usia Kehamilan}

Hasil penelitian menunjukkan bahwa usia kehamilan mayoritas berada pada trimester III sebesar 53,3\% dan selebihnya berada pada trimester II yaitu $46,7 \%$. Rentang usia kehamilan trimester I adalah dari 0 minggu-12 minggu, trimester II dari 13 minggu-28 minggu, dan trimester III dari 29 minggu-40 minggu (Marotz \& Kupzyk, 2018). Hasil ini juga sesuai dengan Winarno (2017) bahwa sebagian besar usia kehamilan ibu dengan hipertensi berada pada trimester III $(87,8 \%)$ dan sisanya $12,2 \%$ pada trimester II.

Berdasarkan hasil penelitian juga ditemukan sebanyak 8 orang $(53,3 \%)$ mengalami hipertensi kronik, 6 orang hipertensi gestasional (40\%), dan 1 orang preeklampsia $(6,7 \%)$. Semua responden berada pada usia kehamilan $>20$ minggu. Irianti et al (2013) menyatakan hipertensi dalam kehamilan yaitu hipertensi kronik bisa terjadi sebelum kehamilan mencapai 20 minggu atau ibu sudah memiliki gangguan hipertensi sebelum hamil. Hipertensi gestasional muncul $>20$ minggu kehamilan tanpa disertai proteinuria dan preeklampsia muncul $>20$ minggu disertai proteinuria. Sedangkan menurut Hurt, Guile, Bienstock, Fox, dan Wallach (2011) menjelaskan untuk jenis hipertensi selain hipertensi kronik semuanya timbul setelah 20 minggu kehamilan.

Usia kehamilan yang sudah >20 minggu akan menyebabkan sistem kardiovaskuler bekerja lebih keras untuk mencukupi kebutuhan janin dalam kandungan sehingga berdampak pada tekanan darah yang akan cenderung lebih tinggi dari sebelumnya. Ibu yang memiliki tekanan darah tinggi pada lapisan endometriumnya, lumen arteri tidak melebar sehingga suplai oksigen dan nutrisi 
Pegi Melati, Yulia Irvani Dewi, dan Reni Zulfitri, Efektivitas Terapi Murottal Al-Qur'an terhadap Tekanan Darah Ibu Hamil dengan Hipertensi

menjadi tidak adekuat yang menyebabkan pembuluh darah bekerja lebih berat untuk memenuhi kebutuhan oksigen dan nutrisi janin (Rohen \& Lutjen-Drecoll, 2009).

\section{c. Gravida}

Sebanyak 8 orang $(53,3 \%)$ ibu hamil hipertensi primigravida, 5 orang multigravida $(33,3 \%)$, dan 2 orang grandemultigravida $(13,3 \%)$ dalam penelitian ini. Ibu hamil yang mengalami kehamilan pertama memiliki risiko lebih besar dibandingkan kehamilan setelahnya. Kehamilan pertama merupakan kehamilan yang berisiko dikarenakan belum siapnya organ-organ internal ibu menerima keberadaan janin (fisik ibu) dan ketidaksiapan mental (psikis ibu) (Sudargo, Aristasari, \& 'Afifah, 2018).

Prawirohardjo (2010) juga menjelaskan bahwa munculnya hipertensi pada kehamilan memiliki faktor risiko, salah satunya adalah primigravida. Keman (2014) menjelaskan bahwa faktor resiko primigravida yang biasanya terjadi pada kehamilan pertama ini disebabkan karena terpapar oleh vili korionik untuk pertama kalinya. Hal ini disebabkan mekanisme imunologik yang membentuk blocking antibody oleh HLA-G (Human Leucocyte antigen-G) terhadap antigen plasenta tidak sempurna sehingga proses implantasi menjadi terganggu. Pada awal perkembangan plasenta (remodeling vascular placenta) terjadi transformasi yang tidak lengkap. Invasi sitotrofoblas dari arteri terbatas pada permukaan desidua dan menyebabkan segmen miometrium tetap sempit dan vasokontriksi, sehingga menyebabkan terjadinya hipertensi.

Penelitian oleh Denantika, Serudji, dan Revilla (2015) juga didapatkan proporsi primigravida yang pre-eklampsia 1,52 kali lebih banyak dibandingkan dengan primigravida tidak pre-eklampsia. Penelitian lain oleh Prianita (2011) bahwa preeklampsia cukup tinggi pada primigravida usia yang produktif (20-35 tahun) dengan persentase $80,2 \%$.

\section{Terapi Murottal Al-Qur'an terhadap}

\section{tekanan darah ibu hamil dengan hipertensi}

Terapi murottal Al-Qur'an efektif terhadap penurunan tekanan darah pada ibu 
hamil hipertensi $\{p$ value $=0,001(\alpha=0,05)\}$. Rata-rata tekanan darah sistolik pre-test dari hari 1 sampai hari ke 6 adalah 137,22 mmHg dan post-test $131,05 \mathrm{mmHg}$, terjadi penurunan sebesar 6,17 mmHg. Sedangkan tekanan diastolik rata-rata $89 \mathrm{mmHg}$ menjadi 83,5 $\mathrm{mmHg}$, terjadi penurunan sebesar 5,5 $\mathrm{mmHg}$.

Terjadinya penurunan tekanan darah disebabkan bacaan Al-Qur'an mampu memberikan kesan positif terhadap tubuh sebagaimana yang dijelaskan oleh Pedak (2009) bahwa Al-Qur'an memberikan efek positif pada hippocampus dan amygdala yang menimbulkan suasana hati (emosi) positif. Penelitian Aini, Wulandari, dan Astuti (2017) juga menunjukkan bahwa mendengarkan Al-Qur'an memberi dampak positif dalam menurunkan tekanan darah $\{p$ value $=0,000$ $(\alpha=0,05)\}$

Pedak (2009) menjelaskan bahwa bacaan Al-Qur'an ketika ditangkap oleh indera pendengaran yaitu telinga, kemudian telinga akan melalui proses mendengarkan. Fisiologinya dimulai dengan telinga menerima suara, membedakan frekuensi, dan mengirim informasi menuju sistem saraf pusat. Sinyal yang masuk akan berinteraksi dengan sel-sel otak, terutama pada amigdala (pusat emosi), hipokampus (pusat ingatan emosional), dan area pre-frontal (pemaknaan peristiwa) yang akan berpengaruh pada turunnya ketegangan urat saraf reflektif dan menghasilkan ketenangan.

Thayyarah (2014) menjelaskan bahwa pengaruh yang ditimbulkan menyebabkan arus listrik di otot mengalami perubahan, detak jantung dan sirkulasi darah menjadi stabil. Semua pengaruh ini menunjuk kepada perubahan fungsi dan kinerja sistem saraf otonom. Susunan saraf otonom yang terdiri dari saraf simpatis dan parasimpatis diaktifkan dan dikendalikan oleh amigdala yaitu sebagai pusat emosi. Rangsangan saraf otonom yang terkendali akan mem-blocking pembentukan angiotensin sehingga tekanan darah menjadi turun.

Sesuai dengan penelitian sebelumnya oleh Pratiwi, Hasneli, dan Ernawaty (2015) mengenai Murottal Al-Qur'an terhadap tekanan darah pasien hipertensi primer menunjukkan bahwa gelombang suara yang dihasilkan membuat hormon endofrin alami 
Pegi Melati, Yulia Irvani Dewi, dan Reni Zulfitri, Efektivitas Terapi Murottal Al-Qur'an terhadap Tekanan Darah Ibu Hamil dengan Hipertensi

tubuh diaktifkan, hormon stress menurun dan meningkatkan perasaan rileks yang hasilnya menurunkan tekanan darah. Penelitian lain Kartini, Fratidhina, dan Kurniyati (2016) juga menunjukkan mendengarkan Al-Qur'an berpengaruh menurunkan tekanan darah ibu hamil preeklampsi.

Pada penelitian ini peneliti menggunakan murottal dengan memakai lima macam surah yang disertai dengan terjemahan masing-masing ayat. Peneliti lebih memilih memakai terjemahan ayat dikarenakan efek yang akan ditimbulkan akan berbeda dengan tanpa disertai terjemahan. Surah yang disertai dengan terjemahan ayatnya akan memberikan kesan yang lebih dibandingkan dengan hanya mendengarkan surah tanpa terjemahan ayatnya. Hal ini dijelaskan oleh Pedak (2009) bahwa mendengarkan ayat Al-Qur'an dengan disertai maknanya akan melewati area wernicke dan area prefrontal (pemaknaan peristiwa), sedangkan mendengarkan bacaan Al-Qur'an tanpa disertai maknanya tidak melalui area tersebut. Area wernicke adalah untuk interpretasi (menafsirkan atau memberikan kesan). Oleh karena itu murottal ayat Al-Qur'an akan memberikan efek yang lebih positif dan berkesan dibandingkan dengan tanpa disertai maknanya.

Bacaan ayat Al-Qur'an menurut Saleh (2018) dapat meningkatkan imunitas tubuh dikarenakan gelombang suara yang dihasilkan mempunyai frekuensi yang khas dan memicu sel secara keseluruhan. Sebagaimana penyebab hipertensi dalam kehamilan menurut teori adalah karena faktor imunologik yang dapat menganggu sistem imun ibu dan menyebabkan masalah transport kapiler yang menimbulkan vasospasme dan peningkatan tekanan darah, maka dengan murottal Al-Qur'an dapat mempengaruhi perubahan tekanan darah.

Pernyataan tersebut dibuktikan oleh hasil penelitian Julianto dan Subandi (2015) dengan hasil bacaan Al-Qur'an dapat meningkatkan imunitas disebabkan hypothalamus mengaktifkan adenohipofisis untuk melepaskan hormon trofik dan merangsang kelenjar adrenal agar tidak mensekresi kortisol dalam darah sehingga meningkatkan imunitas yang signifikan yang berdampak pada 
perubahan tekanan darah.

Murottal Al-Qur'an disertai makna yang telah diterapkan kepada responden mampu mensekresikan hormon kebahagiaan yaitu endorfin dan serotonin. Ditunjukkan dengan adanya penurunan tekanan darah responden setelah diberikan terapi dan tidak ada responden yang mengalami kenaikan tekanan darah setelah diberikan terapi tersebut.

Hormon endorfin merupakan hormon kebahagiaan yang dihasilkan tubuh secara alami dengan sifatnya serupa dengan narkotika yang dapat menciptakan perasaan nyaman (Kuswandi, 2014).

Astawan dan Leomitro (2009) menjelaskan bahwa hormon serotonin fungsinya hampir sama dengan endorfin yaitu berperan dalam menginduksi relaksasi. Hormon serotonin juga berfungsi menyesuaikan kapasitas kerja otak termasuk mengatur stabilitas emosi. Kemudian hormon serotonin diubah menjadi melatonin yang secara alami dihasilkan tubuh ketika matahari mendekati senja yang berefek kepada regulasi relaksasi tubuh, sehingga penelitian ini dilakukan pada sore hari menjelang senja dan dengan demikian dapat dilihat bahwa terjadi penurunan tekanan darah disebabkan oleh hormon melatonin yang dihasilkan dari mendengarkan lantunan Murottal Al-Qur'an disertai maknanya.

\section{SIMPULAN}

Hasil penelitian efektivitas terapi Murottal Al-Qur'an terhadap ibu hamil dengan hipertensi menunjukkan sebagian besar ibu hamil dalam rentang usia 20-35 tahun $(66,7 \%)$. Sedangkan karakteristik usia kehamilan semua responden >20 minggu, kecuali satu responden dan status gravida sebagian besar primigravida (53,3\%). Tekanan darah sistolik menurun sebesar 6,17 mmHg dan diastolik sebesar 5,5 mmHg. Analisis uji wilcoxon diperoleh rata-rata sistolik dan diastolik $p$ value $=0,001$ $(\alpha=0,05)$. Hasil ini membuktikan bahwa pemberian terapi mendengarkan ayat Al-Qur'an dan terjemahannya efektif dalam menurunkan tekanan darah ibu hamil hipertensi dengan $p$ value $<\alpha$.

\section{SARAN}

Bagi institusi kesehatan, menjadi bahan 
Pegi Melati, Yulia Irvani Dewi, dan Reni Zulfitri, Efektivitas Terapi Murottal Al-Qur'an terhadap Tekanan Darah Ibu Hamil dengan Hipertensi

informasi dan masukan bagi pengembangan ilmu di bidang kesehatan dan dapat digunakan sebagai pedoman penatalaksanaan terapi non-farmakologis, non invasif, dan mudah diterapkan ibu hamil hipertensi.

Bagi masyarakat, penelitian ini diharapkan khususnya ibu hamil dengan hipertensi dapat menjadikan terapi Murottal Al-Qur'an sebagai bentuk pilihan terapi non farmakologis.

Bagi peneliti selanjutnya, penelitian ini diharapkan memberikan informasi dan melanjutkan penelitian terkait Murottal Al-Qur'an dengan membandingkan efektivitas terapi disertai terjemahan dan tidak disertai terjemahan ayatnya.

\section{DAFTAR PUSTAKA}

Abrahams, P. (2014). Panduan kesehatan dalam kehamilan semua yang harus anda ketahui, dari pembuahan sampai kelahiran bayi (Victor Setyadi, Penerjemah). Tangerang Selatan: KARISMA Publishing Group.

Aini, D.N., Wulandari, P., \& Astuti, S.P. (2017). Pengaruh terapi murottal Al-Qur'an terhadap tekanan darah pada pasien hipertensi. Jurnal Ners Widya Husada Semarang, 3 (2). Diperoleh tanggal 10 Januari 2019 dari http://stikeswh.ac.id.

Astawan, M., \& Leomitro, A. (2009). Khasiat whole grain. Jakarta: Gramedia Pustaka Utama.

Basana, L.D.U., Myrnawati., \& Sembiring, R. (2017). Faktor-faktor yang mempengaruhi kejadian hipertensi pada kehamilan studicase control. Jurnal Ilmiah Kohesi, 1 (3). Diperoleh tanggal 19 Juni 2019 dari http://sciencemakarioz.org/jurnal/kohesi.

Denantika, O., Serudji, J., \& Revilla, G. (2015). Hubungan status gravid dan usia ibu terhadap kejadian preeklampsia. Jurnal Kesehatan Andalas, 4 (1). Diperoleh tanggal 14 Juni 2019 dari http://jurnal.fk.unand.ac.id.

Dinas Kesehatan Kota Pekanbaru. (2017). Profil data kesehatan Kota Pekanbaru. Pekanbaru: Dinkes Kota Pekanbaru.

Dinas Kesehatan Provinsi Riau. Profil kesehatan Provinsi Riau. Diperoleh tanggal 13 Desember 2018 dari http://depkes.go.id/.

Endjun, J.J. (2009). Mempersiapkan kehamilan sehat. Jakarta: Pustaka Bunda.

Gunawan, S. (2010). Mau anak laki-laki atau perempuan bisa diatur. Jakarta: Agromedia Pustaka.

Hurt, K.J., Guile, M.W., Bienstock, J.L., Fox, H.E., \& Wallach, E.E. (2011). The johns hopkins manual of gynecology and obstetrics. United States: Lippincott Williams \& Wilkins.

Indriyani, D. (2013). Keperawatan maternitas pada area perawatan antenatal. Yogyakarta: Graha Ilmu.

Irianti, B., dkk. (2014). Asuhan kehamilan berbasis bukti paradigma baru dalam 
asuhan kebidanan. Jakarta: Sagung Seto.

Julianto, V., \& Subandi. (2015). Membaca Al-Fatihah reflektif intuitif untuk menurunkan depresi dan meningkatkan imunitas. Jurnal Psikologi, 42 (1). Diperoleh tanggal 8 Januari 2019 dari https://jurnal.ugm.ac.id

Jumaiza, J., Elvira, D., \& Panjaitan, A.A. (2018). Analisis Faktor-faktor yang berhubungan dengan kejadian hipertensi pada ibu hamil trimester III. Jurnal Ilmiah Ilmu Kesehatan, 4 (2). Diperoleh tanggal 19 Juni $2019 \quad$ dari http://journal.stikes-kapuasraya.ac.id.

Kartini., Fratidhina, Y., \& Kurniyati, H. (2016). Pengaruh mendengarkan murottal terhadap penurunan tekanan darah pada ibu hamil preeklampsi. Jurnal JKFT, 2, 45-46. Diperoleh tanggal 15 Desember 2018 dari http://jurnal.umt.ac.id

Keman, K. (2014). Patomekanisme preeklampsia terkini mengungkapkan teori-teori terbaru tentang patomekanisme preeklampsia dilengkapi dengan deskripsi biomokuler. Malang: UB Press.

Kementrian Kesehatan Republik Indonesia. Profil kesehatan Indonesia. Diperoleh tanggal 13 Desember 2018 dari http://depkes.go.id.

Khosravi, S., Dabiran, S., Lotfi, M., \& Asnavandy, M. (2014). Study of the Prevalence of Hypertension and Complications of Hypertensive Disorders in Pregnancy. Open Journal of Preventive Medicine, 4, 860-867. Diperoleh tanggal 14 Desember 2018 dari http://dx.doi.org/10.4236/.

Kuswandi, L. (2014). Hypno-birthing a gentle way to give birth. Jakarta: Pustaka Bunda.
Lukito, A. (2017). Pengaruh membaca Al-Quran terhadap tekanan darah pada lansia dengan hipertensi. Anatomica Medical Journal, 1 (3), 120-121. Diperoleh dari http://jurnal.umsu.ac.id.

Mardjan. (2016). Pengaruh kecemasan pada kehamilan primipara remaja. Pontianak: Universitas Muhammadiyah Press.

Marotz, L.R., \& Kupzyk, S. (2018). Parenting today's children: a developmental perspective. Canada: Nelson Education.

Pedak, M. (2009). Mukjizat terapi Qur'an untuk hidup sukses. Jakarta: Wahyumedia.

Pratiwi, L., Hasneli, Y., \& Ernawaty, J. (2015). Pengaruh teknik relaksasi benson dan murottal Al-Qur'an terhadap tekanan darah pada penderita hipertensi primer. Jurnal Online Mahasiswa, 2 (2). Diperoleh tanggal 15 Juni 2019 dari http://jom.unri.ac.id.

Prawirohardjo, S. (2010). Ilmu kebidanan. Jakarta: Bina Pustaka.

Prianita, A.W. (2011) Pengaruh faktor usia ibu terhadap keluaran maternal dan perinatal pada persalinan primigravida. Jurnal kedokteran undip, 1-16. Diperoleh dari http://eprints.undip.ac.id.

Rohen, J.W., \& Lutjel-Drecoll, E. (2009). Embriologi fungsional. Jakarta: EGC.

Ropei, O., \& Luthfi, M. (2017). Pengaruh terapi psikoreligi murottal Al-Qur'an terhadap tekanan darah pada klien dengan hipertensi. Jurnal Keperawatan 'Aisyiyah, 4 (1), 1-12. Diperoleh tanggal 20 Februari 2019 dari http://jurnalkeperawatan.stikes-aisyiyahba ndung.ac.id.

Saleh, A.Y. (2018). Berzikir untuk kesehatan syaraf. Jakarta: Hikaru Publishing. 
Pegi Melati, Yulia Irvani Dewi, dan Reni Zulfitri, Efektivitas Terapi Murottal Al-Qur'an terhadap Tekanan Darah Ibu Hamil dengan Hipertensi

Sudargo, T., Aristasari, T., \& 'Afifah, A. (2018). 1000 hari pertama kehidupan. Yogyakarta: Gadjah Mada University Press.

Thayyarah, N. (2014). Buku pintar sains dalam Al-Qur'an mengerti mukjizat ilmiah firman Allah (Zaenal Arifin, Nurkaib, Iman Firdaus, \& Nur Hizbullah, Penerjemah). Jakarta: Zaman.

Winarno, T. (2017). Karakteristik ibu hamil dengan preeklampsia. Jurnal Kesehatan Universitas Muhammadiyah Surakarta, 4-5. Diperoleh tanggal 19 Juni 2019 dari http://eprints.ums.ac.id.

World Health Organization. (2018). Guideline: maternal mortality. Diperoleh tanggal 12 Januari 2019 dari https://www.who.int/. 